\title{
EDITORIALS
}

\section{THE URANIUM AND RADIUM SITUATION}

Some months since, rumors reached the U. S. Bureau of Mines of an increased demand for carnotite ores from Colorado and that these ores were being shipped abroad in some quantity. Further, it was reported that the methods of production involved large losses of material and that methods for concentrating lowgrade material now being thrown on the dump were greatly needed. Accordingly, Messrs. R. B. Moore and $\mathrm{K}$. L. Kithil were assigned to the task of investigating the situation with headquarters at Denver, where the Bureau established a laboratory for the purpose of investigating the rarer metals occurring in the western part of the United States and problems bearing upon the prevention of waste and increased efficiency in the mining industry. The surprising conclusion has been reached that while all the radium placed upon the market in the last few years has been produced in Europe, a large portion of this output has come from American ores.

Radium institutes have been established in Austria, France, Germany and England, a European science and industry have been developed from American radium ores and even the uranium present with the radium has been manufactured into marketable condition only in foreign countries and returned in finished condition to our own. American hospitals and physicians have been forced to procure from abroad such radium as they could afford for experimental purposes, and investigations in our governmental and university laboratories of the wonderful properties of radium and their possible application to the eradication of disease and the development of industry have been hampered by the almost prohibitive prices at which the finished material is held.

While the Austrian government, realizing the untold possibilities of the radium ores of St. Joachimsthal, has purchased the mines, put their output under direct governmental supervision, and has entered into an arrangement whereby this ore is worked up in coöperation with the Vienna Academy of Sciences for experimental purposes in a carefully administered radium institute, America has allowed her large and much greater resources to be exploited on a basis which wastes perhaps irretrievably a large portion of the material mined, and has exported carefully selected ores at a price by no means commensurate with their radium value if worked up at home.

Even before carnotite was exported, pitchblende of the highest grade was sent out of the country at a time when the world's radium output was supposed to be coming from Austrian ores. At least 20-2 5 tons of high-grade pitchblende have been sent out of the country. Within the last two years, however, foreigners have realized the value of our carnotite resources, and most of the radium that has been exported has gone abroad in this ore.
During the last year, carnotite was produced carrying 28.8 tons of $\mathrm{U}_{3} \mathrm{O}_{8}$, from which $8.8 \mathrm{grams}$ of radium chloride or I I. 43 grams of radium bromide could be obtained. Practically all of this ore was shipped abroad for the extraction of radium. The value of the radium salts extracted would be $\$_{528,000}$ at the minimum market price. The total supply of radium salts from all other sources including the Austrian mines was probably not more than 3.65 grams of radium chloride, basing the production of the Austrian mines for Igr 2 upon that of IgI I which is known.

Pitchblende, the richest of all uranium minerals, is composed mainly of uranium oxide but also carries lesser quantities of a large number of other substances. It has been found in small quantities in Connecticut and in the feldspar quarries of North Carolina. Practically the total American output has come from the mines in Quartz Hill, Gilpin County, Colorado. The mineral is a heavy, black substance which can be readily identified by any one by suspending a sample of the pitchblende above a photographic plate wrapped in black paper and kept in the dark for a few days with a key or other metal object opaque to radium radiations placed between the sample of ore and the plate so that when the plate is developed a shadowgraph will identify the ore. Pitchblende may carry as high as 80 per cent. uranium oxide, although the average ore is not nearly so rich.

Carnotite is a yellow mineral consisting mainly of potassium uranyl vanadate but containing also small amounts of barium and calcium compounds. Being a uranium mineral, as is pitchblende, it of necessity carries radium, although it has not yet been definitely established that the uranium and radium are in equilibrium as they are in pitchblende. However, it is known that in our western carnotite the amount of radium is not far from the equilibrium ratio and in the calculations given above an allowance of ro per cent. has been made to cover this possible deficiency.

While carnotite is known to occur in smaller quantities in other states, the more important deposits are scattered over a considerable area in Colorado and Utah, embracing Meeker and Skull Creek, Colo, Green River, Thompson's, Moab, Richardson, Table Mountain, Pahreah, and other places in Utah. The largest proportion of the ore, however, has been produced in or around Paradox Valley in southwest Colorado, from which it has to stand long hauls by pack animal or wagon to the railroad. Carnotite always carries vanadium as well as uranium and radium but is purchased almost wholly on its radium content, comparatively little being allowed for the vanadium present.

The ore, consisting of a fine-grained sandstone containing yellow finely pulverulent carnotite, occurs 
in pockets and is easily mined. As ore below 2 per cent. uranium oxide cannot at the present time find a market, a considerable portion of the ore has been thrown on the dump and is now being wasted, as material of lower grade has to be discarded on account of the long haul and the fact that European buyers have set this standard as to quality. Ores of higher grade are sometimes obtained but they occur only in small pockets and it is generally advisable to mix these high-grade ores with ores of somewhat lower content in order to increase the marketable output. Ore of 2 per cent. uranium oxide is now worth approximately $\$ 75$ per ton f. o. b. New York. In the mining of these carnotite ores, it is probable that 5 tons of material capable of concentration are thrown upon the dump for every ton that finds its way to market. To develop methods for concentration of these ores and save the valuable material now wasted is one of the problems before the Bureau of Mines with fair prospect of a successful conclusion.

It is difficult to estimate the total amount of radium that has been produced up to the present time, but it is quite certain that if the ores which have been mined in this country and abroad and sold for radium production have been actually worked up into this material, there is now in existence something like 40 grams ( $\mathrm{I} / 4$ ounces) of radium. The price of radium salts varies somewhat. In large quantities it has been $\$ 60,000$ per gram for both radium chloride and radium bromide, although the latter contains less metallic radium in proportion to its weight than the former. It should be remembered, therefore, that it is more advantageous to purchase radium chloride than radium bromide. In small quantities the average price has been $\$ 80,000$ per gram which represents about $\$ 2,250,000$ an ounce.

The figures given show very plainly that the United States has taken the palm from Austria as the radiumproducing country of the world. Very few people have been cognizant of the fact that the United States has such deposits within her borders. Up to the present time very little interest has been taken in the matter, and only one firm has engaged in the extraction and refining of radium in this country-a condition which is deplorable. This firm has not yet entered the radium market.

Practically every ton of ore mined in IgI 2 went abroad, and as the American deposits are far from being inexhaustible we are rapidly depleting our own reserve and are shipping from the country material which cannot be replaced and which is of great value and of unknown possibilities.

The applications of radium are still too little understood to admit of definite statement. Its discovery and marvelous properties have already changed our ideas regarding the constitution of matter, and scientific investigation will undoubtedly lead to valuable results which we cannot now even foresee. Altogether too many incorrect statements and vague speculations have been placed before the public as to its use in medicine. A recent report of the London Radium Institute and the many articles emanating from minor laboratories experimenting in the application of radium to therapeutics all tend to show, however, that it has a real value. the certain application of which must await further experimentation. In the meantime no credence should be given to the many stories that are sure to be printed. unless they are backed up by the highest medical authority which will always give publicity with caution. The best medical authorities appear to agree that, up to the present time, radium has not been proved to be a specific for any disease, although it has been shown to be helpful in many cases. The outlook for its future application to certain diseases not easily treated otherwise is decidedly encouraging.

Apparently no uranium is worked up in the United States, but according to statistics gathered by the division of mineral resources of the UT. S. Geological Survey, about $\$_{14}, 000$ worth of its oxides and salts were imported into the United States in IgII. It is one of the few materials shipped abroad as ore and returned in manufactured form.

A preliminary report on uranium, radium and vanadium by $R$. B. Moore and $K$. L. Kithil will soon be issued by the Bureau of Mines. This bulletin describes the carnotite deposits of Colorado and Utah and the pitchblende deposits of the former State. It also contains detail, of which the foregoing is simply a general summary, which cannot fail to be of value to all those interested in our mineral resources and their development.

Chartes L. Parsons. ${ }^{\mathrm{r}}$

\section{SOME DEVELOPMENTS OF THE IRON AND STEEL INDUSTRY}

In this résumé of developments of an industry, only those points of more common interest or significance can hope to be touched and others of equal importance are doubtless overlooked. Only the peaks can be mentioned and these in general terms, for the most part. In general, progress in all industries synchronizes to a large extent and points here referred to correlate with some in other lines-each making possible reciprocal advances in the other.

Naturally, the subject of first importance is the ore supply. Doubtless since the beginning of iron making, the exhaustion of ore supplies has been the subject of serious consideration by some. The first exhaustive studies were those of the Swedish geologists, Tiberg in 1898 and Tornebohm in 1905 . The latter's estimates indicated most serious depletion of resources within fifty years and with the most generous allowances for new discoveries, a serious condition faced the world in a half century, if the rapid growth of production was to continue. Without any analysis of his figures, it may be said that fortunately for

1 Paper presented at the Annual Meeting of the American Chemical Society, Milwallkee, March, 1913, by permission of the Director of the Bureau of Mines. 